\title{
Influence of Drying Process of Liquid Contaminants on Adhesive Bond Strength
}

\author{
Miroslav Müller ${ }^{1}$, Petr Henc ${ }^{1}$, Anna Rudawska² \\ ${ }^{1}$ Faculty of Engineering, Czech University of Life Sciences Prague. Czech Republic. E-mail: muller@tt.czu.cz, \\ henc@tf.czu.cz. \\ ${ }^{2}$ Politechnika Lubelska, Department of Production Engineering, Lublin, Poland. E-mail: a.rudawska@pollub.pl.
}

\begin{abstract}
Regarding effects of environment factors on adhesive bonds belongs among key requirements influencing the adhesive bond strength. The aim of experiments was to set an influence of liquid contaminants on changes of the adhesive bond strength and to set whether a degradation process is an irreversible change that means whether degradation adhesives will restore their strength characteristics depending on the time. The adhesive bonds were placed into three liquid contaminants for the time 1, 2 and 3 months. The testing process was performed after removing specimens from the liquid contaminant (marked as 0 ), then after 24, 72 and $163 \mathrm{~h}$. A considerable fall of the adhesive bond strength has already occurred in the first phase of the testing that means after 1 month of the contamination. The rate of the adhesive bond strength fall caused by the degradation process is in the interval 10 till $92 \%$. This undesirable process can be subsequently suppressed by a drying process of the liquid contaminant. The experiment results certified in most cases a positive influence of the drying process of the liquid contaminants on the adhesive bond strength.
\end{abstract}

Keywords: Adhesive bond, degradation, exposing, two-component epoxy, testing

\section{Acknowledgement}

This paper has been done when solving the grant IGA TF (No.: 2014:31140/1312/3133).

\section{References}

[1] MÜLLER, M. (2013). Research of Liquid Contaminants Influence on Adhesive Bond Strength Applied in Agricultural Machine Construction. In: Agronomy Research, Vol. 11, pp. 147-154.

[2] MÜLLER, M., HERÁK, D. (2013). Application possibilities of adhesive bonds - Europe, Indonesia. In: Scientia Agriculturae Bohemica, Vol. 44, pp. 167-171.

[3] MESSLER, R. W. (2004). Joining of materials and structures from pragmatic process to enabling technology. Burlington: Elsevier, 815 pp.

[4] MÜLLER, M., VALÁŠEK, P. (2012). Degradation medium of agrokomplex - adhesive bonded joints interaction. In: Research in Agricultural Engineering, Vol. 58, pp. 83-91.

[5] CIDLINA, J., MÜLlER, M., VALÁŠEK, P. (2014). Evaluation of Adhesive Bond Strength Depending on Degradation Type and Time. In: Manufacturing Technology, Vol. 14, No. 1, pp. 8-12.

[6] MÜLLER, M., RUŽBARSKÝ, J., VALÁŠEK, P. (2014). Degradation process in area of connecting metal sheets by adhesive bonding technology in agrocomplex. In: Applied Mechanics and Materials. Vol. 616, pp. 52-60.

[7] CROCOMBE, A., D., HUA, Y., X., LOH, W., K., WAHAB, M., A., ASHCROFT, I., A. (2006). Predicting the residual strength for environmentally degraded adhesive lap joints. In: International Journal of Adhesion $\&$ Adhesives, Vol. 26, pp. 325-336.

[8] LOH, W., K., CROCOMBE, M., M., ABDEL WAHAB, I., A. (2003). Modelling interfacial degradation using interfacial rupture elements. In: Journal of adhesion, Vol. 79, pp.1135-1160.

[9] RUDAWSKA, A. (2014). Selected aspects of the effect of mechanical treatment on surface roughness and adhesive joint strength of steel sheets. In: International Journal of Adhesion and Adhesives, Vol. 50, pp. 235-243.

[10] COMYN, J. (1990). Surface treatment and analysis for adhesive bonding. In: International Journal of Adhesion \& Adhesives, Vol. 10, p. 161-165.

[11] MÜLLER, M. (2011). Influence of Surface Integrity on Bonding Process. In: Research in Agricultural Engineering, Vol. 57, pp. 153-162.

[12] NOVÁK, M. (2012). Surfaces with high precision of roughness after grinding. In: Manufacturing technology, Vol. 12 , pp. $66-70$.

[13] NOVÁK, M. (2011). Surface quality of hardened steels after grinding. In: Manufacturing technology, Vol. 11, pp.55-59. 
[14] HOLEŠOVSKÝ, F., NÁPRSTKOVÁ, N., NOVÁK, M. (2012). GICS for grinding process optimization. In: Manufacturing technology, Vol. 12, pp. 22-26.

[15] KROLCZYK, G., LEGUTKO, S. (2013). The machinability of duplex stainless steel-solutions in practice. In: Manufacturing technology, Vol. 13, pp. 473-478.

[16] HOLEŠOVSKÝ, F., NOVÁK, M., LATTER, M., VYSLOUZIL, T. (2013). Machining and its influence to surface quality of machine parts. In: Key Engineering Materials. Vol. 581. pp. 354-359.

[17] JÓZWIK, J., KURIC, I., SÁGA, M., LONKOWIC, P. (2014). Diagnostics of CNC machine tools in manufacturing process with laser interferometer technology. In: Manufacturing technology, Vol. 14, pp. 23-30.

[18] NOVÁK, M. (2013). New ways at the fine grinding. In: Key Engineering Materials. Vol. 581. pp. 255-260.

[19] BALKOVA, R., HOLCNEROVA, S., CECH, V. (2002). Testing of adhesives for bonding of polymer composites. In: International Journal of Adhesion \& Adhesives, Vol. 22, pp. 291-295.

[20] MÜLLER, M. (2013). Research of renovation possibility of machine tools damage by adhesive bonding technology. In: Manufacturing Technology, Vol. 13, pp. 504-509.

[21] KINLOCH, A., J., OSIYEMI, S., O. (1993). Predicting the fatigue life of adhesively-bonded joints. In: Journal of adhesion. Vol. 43, pp. 79-90. 